\title{
Infection in the fins of the goldfish Carassius auratus caused by Myxobolus diversus (Myxosporea)
}

\author{
Kálmán Molnár and Csaba Székely \\ Veterinary Medical Research Institute, Hungarian Academy of Sciences, P.O. Box 18, H-1581 Budapest, Hungary
}

Key words: Myxosporea, Myxobolus diversus, goldfish, fins, histopathology

\begin{abstract}
During health surveys of 7- to 9-week-old goldfish (Carassius auratus L.) fingerlings in a fish farm near Budapest, Hungary, myxosporean plasmodia were observed on the fins. Plasmodia were most frequently found at the intersegmental joints of the finrays. Spores of Myxobolus diversus Nie et Li, 1973 known from China, were detectable in the mature plasmodia located within the lumen, and less often on the surface, of the cartilaginous finrays. The external wall of the plasmodia was constituted by a capsule formed from a collagenous material identical with the cartilaginous substance of the finrays. Matured plasmodia were filled by spores of $12-14 \times 8-9.5 \mu \mathrm{m}$ in size. The relatively small plasmodia caused only small deformities on the fins. Their importance is, however, not negligible, as in an ornamental fish such as the goldfish even a minor damage of the fins causes a loss of value. Besides a report on the first European occurrence and pathological aspects, a redescription of this parasite of Far-Eastern origin is given.
\end{abstract}

The goldfish (Carassius auratus L.) is a popular ornamental fish species of Far-Eastern origin, which is kept in aquaria and small ornamental ponds all over the world. In Hungary it is regularly cultured as a commodity fish by intensive farming methods in the ponds of the Warm-water Fish Hatchery of Százhalombatta, a fish farm close to Budapest. A subspecies of the goldfish, the gibel carp (Carassius auratus gibelio Bloch) also originating from the Far East, occurs in the natural waters of Hungary, where it is considered one of the commonest undesirable wild fish species (Pénzes and Tölg 1986). Data on the parasite fauna of the goldfish are available primarily from Japan, China and the former Soviet Union (Akhmerov 1960, Pan et al. 1990, Yokoyama et al. 1993, 1995, Chen and Ma 1998). Although cultured goldfish are under regular animal health supervision in Hungary, due to the relatively problem-free rearing no data exist on its parasitic infections. Few data are available on parasitic infections of the gibel carp as well (Székely and Molnár 19961997). In the original biotope the myxosporean fauna of the two Carassius auratus subspecies is rather large. Akhmerov (1960) detected 13 myxosporean species from gibel carp in the watershed area of the River Amur, while Landsberg and Lom (1991) reported as many as 20 species of the genus Myxobolus Bütschli, 1882 alone from goldfish after processing their FarEastern material. In Hungary numerous known and new species of Myxosporea have been detected from common carp (Cyprinus carpio) reared in fish farms where goldfish were also kept (Molnár 1979, 1980, 2000, Molnár and Kovács-Gayer 1982, Kovács-Gayer and Molnár 1983, Lom and Molnár 1983). Apart from the occurrence of two Sphaerospora species ( $S$. molnari, S. renicola) and Hoferellus carassii no myxosporean infection has been found in goldfish and gibel carp (Molnár 1979, Molnár et al. 1989, Székely and Molnár 1996-1997). Relatively few data can be found on the histological structure of the fins in cyprinids. However, Sharples and Evans (1996), who studied the pathology of fin erosion in goldfish, provided rather detailed information on the anatomical and histological structure of the healthy fins as well.

This paper describes infection of goldfish fingerlings caused by Myxobolus diversus $\mathrm{Nie}$ et $\mathrm{Li}, 1973$ which, regarding its location in the finrays, resembles Thelohanellus nikolskii infection highly prevalent in the Hungarian fish farms.

\section{MATERIALS AND METHODS}

Regular surveys of common carp and koi fry are conducted in the ponds of the Warm-water Fish Hatchery in Százhalombatta near Budapest to assess the prevalence of Thelohanellus nikolskii fin infection that occurs in 7- to 9week-old carp fry in Hungary each year. In conjunction with these surveys, goldfish fingerlings 9 to $13 \mathrm{~cm}$ in length and reared in the neighbouring ponds of the farm were also examined for possible Thelohanellus infection. For these studies, a total of 100 goldfish fingerlings were collected from three ponds of 400, 1000 and $4000 \mathrm{~m}^{2}$ water surface. The fins of live fish were examined under dissecting microscope. Fish showing signs of myxosporean infection were transported alive to the laboratory and subjected to complete parasitological examination. Some of the fins found to be infected were fixed in Bouin's solution, embedded in paraffin wax, cut into $4 \mu \mathrm{m}$ thick sections, and stained with haematoxylin and eosin (H\&E) and according to the Farkas-Mallory method to visualise the cartilaginous substance (Kiszely and Barka 
1958). Images were recorded with the help of a digitising equipment connected with an Olympus BH-2 microscope. The morphological characteristics of the spores were studied according to the guidelines provided by Lom and Arthur (1989).

\section{RESULTS}

Fin infection by a species of Myxosporea was found in $29 \%$ of the examined fish. On the fins of the fish, mostly in the finrays and sometimes bulging out from the latter, mostly spherical plasmodia 1 to $1.8 \mathrm{~mm}$ in diameter were detected. The average number of plasmodia found on one fish was 1-11 (5.8 \pm 3.8$)$. Plasmodia were detectable mostly in the tail fins, but sometimes also on other fins. The plasmodia had a relatively thin capsule and could be dissected out from the finrays in their entirety after the finrays had been pried apart. At the time of the examination, the majority of plasmodia contained mature spores. The spores released by opening the capsule of the plasmodium and by squashing the plasmodium contained two polar capsules by which the parasite could be identified as a member of the genus Myxobolus. One of the polar capsules was fairly rudimentary. By its morphological characteristics and its dimensions the newly found Myxobolus species is identified as Myxobolus diversus Nie and Li, 1973 from goldfish in China. As the original description was published by Nie et Li only in short and in Chinese in the book edited by Chen (1973), a redescription of the species from the Hungarian material is given.

\section{Myxobolus diversus Nie et Li, 1973}

Figs. 1-7

$\mathrm{T}$ y $\mathrm{p}$ e $\mathrm{h}$ o s $\mathrm{t}$ : Carassius auratus L. (Cypriniformes, Cyprinidae).

Site of infection: Fins.

L o c a 1 i t y: Fish farm, Százhalombatta, Hungary.

Vou cher m a teria 1: Deposited in the parasitological collection of the Zoological Department, Hungarian Natural History Museum, Budapest, Coll. No. 16913.

Redescription (based on 25 spores in frontal view and 25 spores in lateral view):

Vegetative stages round or short ellipsoidal plasmodia measuring $1-1.6(1.3 \pm 0.27) \times 1.2-1.8(1.5 \pm 0.23)$ $\mathrm{mm}$. They were located in the cartilaginous finrays where two parts of ray segments joined each other (Fig. 2).

Spores (Figs. 1, 3) ellipsoidal in frontal view, and lemon-shaped in lateral view. Sutural line indistinct, sutural edge moderately protruding. Valves relatively thin, symmetrical and smooth without sutural edge markings. Spores 12-14 (12.8 \pm 0.8$) \mu \mathrm{m}$ long, 8-9.5 (8.7 $\pm 0.7) \mu \mathrm{m}$ wide and $6-7(6.5 \pm 0.5) \mu \mathrm{m}$ thick. Two polar capsules different in size. Larger one pyriform, 4-5.5 (4.5 $\pm 0.6) \mu \mathrm{m}$ long and 2.5-3.5 $(3 \pm 0.5) \mu \mathrm{m}$ wide, tapering toward discharging canals of polar filament only at its

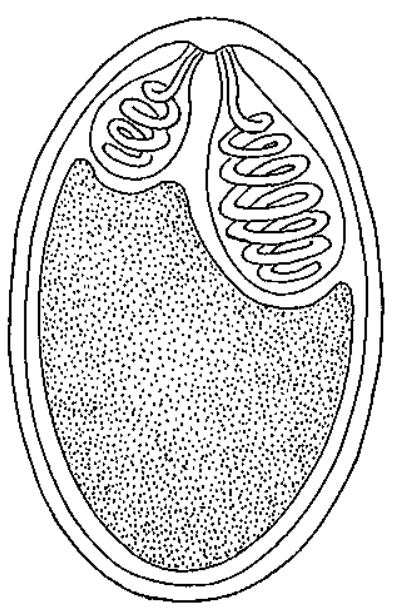

a

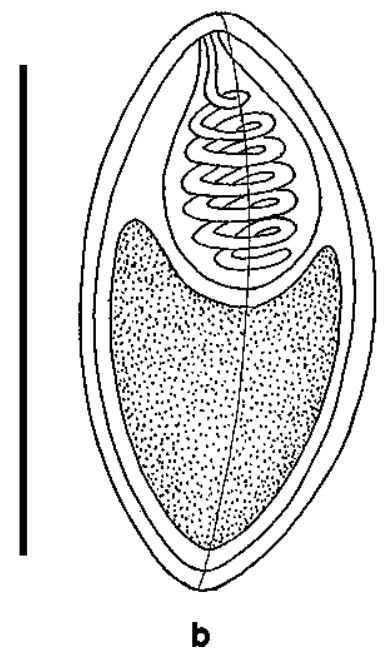

Fig. 1. Spore of Myxobolus diversus, schematic drawings. a frontal view, b - lateral view. Scale bar $=10 \mu \mathrm{m}$.

distal end. Polar filaments coiled with 6 turns in polar capsule, situated perpendicularly to longitudinal axis of capsule. Smaller polar capsule fairly rudimentary, pyriform or elongated, $2.5-3(2.7 \pm 0.2) \mu \mathrm{m}$ long and $1-$ $1.5(1.2 \pm 0.2) \mu \mathrm{m}$ wide, coiled only with 2 or 3 turns. Polar filament of larger capsule 30-40 $(36 \pm 3.4) \mu \mathrm{m}$, that of smaller capsule $11-14(12 \pm 1.4) \mu \mathrm{m}$ long. Spore with small papilla-like intercapsular appendix at anterior end. Sporoplasm nuclei indiscernible, no iodinophilous vacuole found in sporoplasm.

Spores from young plasmodia frequently irregular in shape with indentation in one side (Fig. 3).

\section{Differential diagnosis}

With one of its polar capsules rudimentary, $M$. diversus differs from most Myxobolus species known from Europe. It most closely resembles $M$. thelohanellus Shulman et Wichrova, 1952, a parasite of the crucian carp (Carassius carassius L.), but differs from it by lacking iodinophilous vacuoles, and in the structure of the smaller polar capsule. While $M$. diversus has a less developed but existing second polar capsule, $M$. thelohanellus has only a single polar capsule and the rudimentary second capsule is observable only as an undeveloped nucleus. Differences in size of the two polar capsules have been described also for Myxobolus toyamai Kudo, 1915 and Myxobolus anisocapsularis Shulman, 1962, parasites of the common carp and some Hemibarbus spp., respectively, but the pyriform and elongated spores of these latter species significantly differ from the ellipsoidal spores of $M$. diversus. Several Myxobolus spp. (M. acinosus Nie et Li, 1973, M. egregius Li et Nie, 1973, M. hokiangensis Ma, 1998, M. microsporus $\mathrm{Li}$ et $\mathrm{Nie}, 1973$, and $M$. pinnae $\mathrm{Wu}$ et Chen, 1987) known from China have unequal polar capsules, with one rudimentary. Of them, M. acinosus 

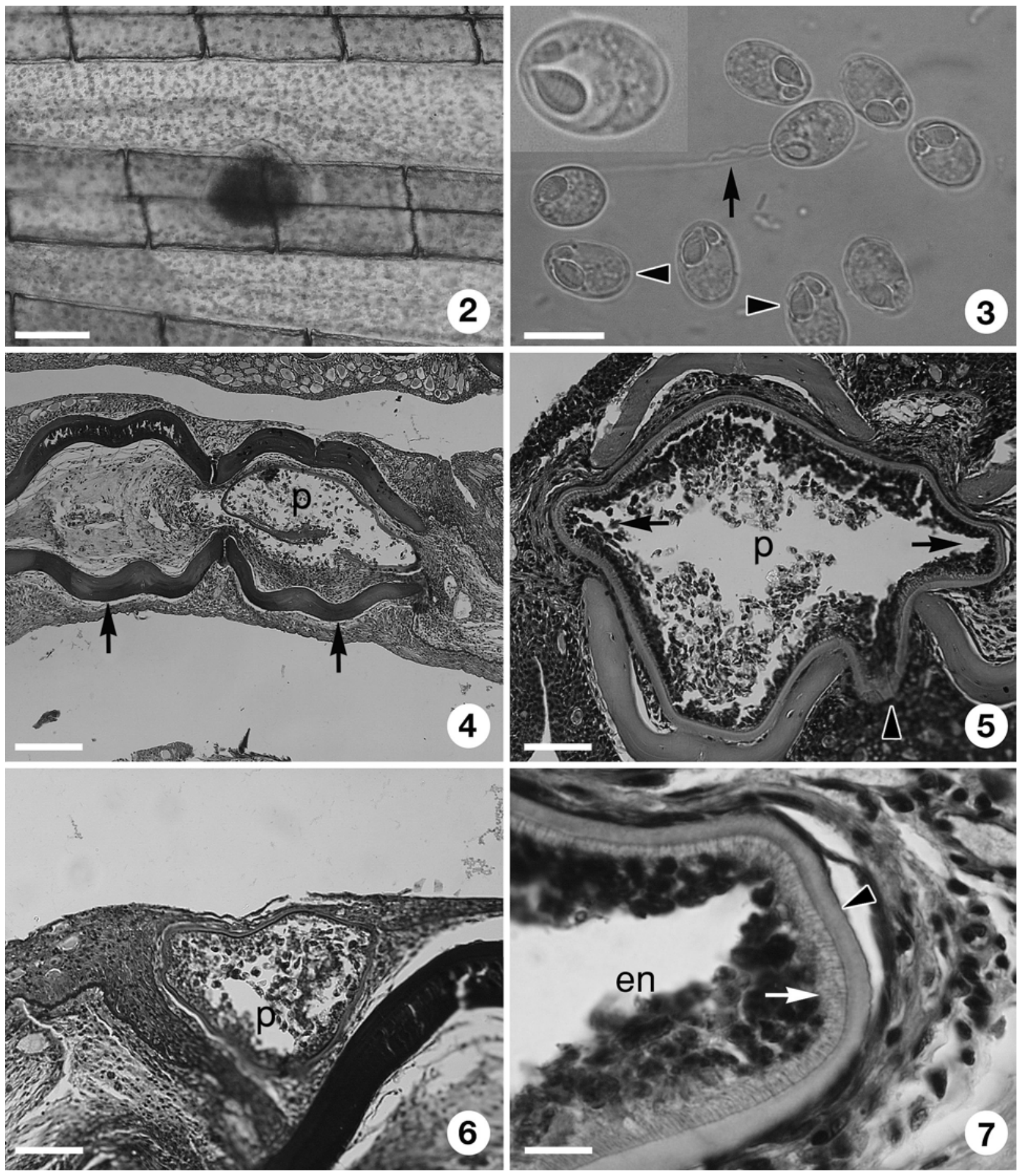

Figs. 2-7. Myxobolus diversus in the goldfish, Carassius auratus. Fig. 2. Plasmodium in the finrays at an intersegmental joint.

Fig. 3. Spores released from a mature plasmodium. One of the spores with extruded polar filaments (arrow). Deformed spores (arrowheads), similar to those depicted by Nie and Li, 1973. Inset - enlarged spore. Fig. 4. Plasmodium (p) in one of the finray doublets. Arrows - cartilaginous hemisegments. Histological section. H\&E. Fig. 5. A more developed plasmodium (p) bulges from the intrasegmental region into the interlepidotrichial space (arrowhead) and into the lumen of the neighbouring finrays (arrows). Histological section. H\&E. Fig. 6. Plasmodium (p) developing on the outer surface of the finrays. Histological section. H\&E. Fig. 7. Part of a plasmodium. Foamy-structured ectoplasm of the plasmodium (arrow) surrounds the sporogonic stages in the endoplasm (en). The ectoplasm is encapsulated by a cartilaginous capsule (arrowhead) originating from the hemisegments. Histological section. H\&E. Scale bars: Fig. $2=1 \mathrm{~mm}$; Fig. $3=10 \mu \mathrm{m}$, inset $=5 \mu \mathrm{m}$; Fig. $4=200 \mu \mathrm{m}$; Figs. $5,6=40 \mu \mathrm{m}$; Fig. 7 $=120 \mu \mathrm{m}$. 
and $M$. microsporus differ from $M$. diversus by the conical shape of the anterior end of the spores, while $M$. egregius differs from $M$. diversus by the relatively small size of the larger polar capsule. In spore morphology $M$. hokiangensis and $M$. pinnae resemble $M$. diversus the most, but both of the latter species were described later than $M$. diversus, therefore after a general revision they could be considered only as junior synonyms. In this respect $M$. pinnae deserves special attention, as this parasite has a similar location in the fins of the grass carp. As yet, however, no Myxobolus infection has been recorded in grass carp cultured in Hungary.

\section{Histopathology}

Plasmodia were located inside the tube-like cartilaginous finrays in the intrasegmental region. Plasmodia inside the finrays were mostly found in regions where two of the longitudinally segmented parts of the finrays join each other (intersegmental joints).

Plasmodia started their development in the intrasegmental region between the two w-shaped cartilaginous hemisegments of the finrays (Fig. 4). Gradually they filled the intrasegmental space, and more developed plasmodia partly bulged into the interlepidotrichial space and the inside of the neighbouring finrays (Fig. 5). Less frequently, plasmodia were located on the outer surface of the hemisegments under the basal lamina (Fig. 6).

The wall of the plasmodium was composed of two layers. The inner layer was of parasite origin and consisted of the thin eosinophilic ectoplasm of the plasmodium. The external layer, however, seemed to be of host origin and composed of a cartilaginous capsule formed by acellular bundles of collagen fibres associated with the surrounding connective tissue (perichondrial cells) which form the cartilage of the hemisegments of the finrays (Fig. 7). Pathological changes were indistinct. In the early stage of plasmodial development the growing plasmodium reduced the volume of the loose connective tissue in the intrasegmental region. In more advanced stages of development the plasmodium filled the whole space of the lumen and pressed the blood vessels and nerves to the periphery, close to the cartilaginous hemisegments. No morphological changes were found in the cartilaginous structure of the hemisegments and no inflammatory reaction was recorded.

\section{DISCUSSION}

Little information is available on the host specificity of different Myxobolus species. It seems probable that the majority of species can develop only in fish species most closely related to their type host. Morphological data and, recently, molecular biological evidence (Zardoya and Doadrio 1999) prove that the closest relative of the genus Carassius is the genus Cyprinus. Molnár (2002) observed that Thelohanellus nikolskii, a parasite causing characteristic lesions in the tail fin of cultured common carp (Cyprinus carpio carpio), occurs regularly though with low prevalence and in the form of smaller plasmodia in the fins of coloured carp (Cyprinus carpio haematopterus), a fish species hitherto considered free of this infection. This has raised the question whether this parasite can colonise the goldfish, a fish species taxonomically closely related to the common carp and cultured in large numbers in the same fish farm. During the studies, plasmodia developing in nearly the same location as $T$. nikolskii were indeed detected; however, the spores found in these plasmodia were not those of $T$. nikolskii but corresponded to a Myxobolus species bearing many characteristics of the genus Thelohanellus. This species is identified with $M$. diversus in this paper. Of the 20 Myxobolus species described from goldfish, a fish species originating from China, M. diversus has morphological characteristics that are fully consistent with those of the parasite found in this survey, although the drawings published by Chen and $\mathrm{Ma}$ (1998) depicted mostly deformed spores having slightly irregular outlines. Because of the relatively thin spore valve, such deformed spores were found among the immature spores and the spores fixed in glycerolgelatin also in this study; however, the mature spores invariably had the regular, symmetric form generally typical of the genus Myxobolus. In morphological appearance, $M$. diversus is very close to $M$. thelohanellus, a parasite described by Shulman and Wichrova (cit. by Donec and Shulman 1984) from crucian carp (Carassius carassius), a close relative of goldfish. It is also close to some species ( $M$. acinosus, $M$. egregius, M. hokiangensis, M. microsporus) known to infect goldfish and to $M$. pinnae infecting grass carp in China (Chen and Ma 1998). However, for reasons detailed in the section of differential diagnosis it can be regarded as a valid species.

The plasmodium development of Myxobolus diversus is associated with connective tissue cells that are also capable of forming chondrifying collagenous extracellular product. The plasmodia of $M$. diversus most often develop inside the cartilaginous finray, do not substantially deform the cartilaginous structure but extend from it, through the lateral hiatus, to the connective tissue among the finrays. The formation of plasmodia exceeding in size the diameter of the finrays is facilitated by the lateral bulge and also by the fact that the plasmodia typically colonise the region connecting the longitudinal segments of the finrays (intersegmental joints). Occasionally plasmodia may also develop on the surface of the cartilaginous finray; however, the formation of cartilaginous islets around the capsule of the plasmodium was not observed even in this case.

The histological findings indicate that $M$. diversus causes only minor local changes on the fins of goldfish. The pathological importance of changes caused by myxosporeans greatly depends on the intensity of parasite colonisation, the size of plasmodia and the 
number of spores, but the type of the attacked organ is also important. Parasites colonising vital organs such as the gills or the brain have much higher pathogenicity. In this regard one of the most pathogenic parasites is Myxobolus cerebralis, which causes neurological symptoms. Substantial damage can be done by species which are less pathogenic at the site of spore formation but start major pathological processes through the obstruction of capillaries by their spores disseminated by the blood stream. The best known representatives of this group are Sphaerospora renicola, forming spores in the kidney, and the muscle parasite $M$. cyprini (Csaba et al. 1984, Molnár and Kovács-Gayer 1985, Dyková and Lom 1988). According to Liyanage et al. (1998), the connective tissue parasite Thelohanellus hovorkai causes haemorrhagic lesions by a similar mechanism, while $T$. nikolskii, a parasite much more prevalent in Hungary but developing on the tail fins, cannot be considered a highly pathogenic species in common carp culture despite the major deformities it causes (Molnár
1982). Considering the above example, the fin lesions caused by $M$. diversus could be considered similarly negligible; however, in goldfish, unlike the common carp, even a minor deformity of the fins is a major value-reducing factor. The low-intensity infection found in the present case caused only minor deformity of the fins. However, it cannot be ruled out that intensive infections may lead to irreversible fin distortions similar to those seen in Thelohanellus nikolskii infection.

Acknowledgements. The authors thank Dr. Pin Nie and Dr. Y.S. Lu, Institute of Hydrobiology, Wuhan, China and Mr. Henry Hong, Department of Zoology, University of Toronto, Canada for information on the Chinese special literature. Thanks are due to Dr. Ferenc Baska and Györgyi Pataki for their help with the histological work. The study was rendered possible by a grant of the Hungarian Scientific Research Fund (project No. T 029200) and by the programme entitled "The quality development of the biological and technological bases of the Hungarian fishing sector", 4/039/2001.

\section{REFERENCES}

AKHMEROV A. Kh. 1960: [Myxosporidia of fishes from the Amur River basin.] Rybn. Khoz. Vnutr. Vodoemov Latv. SSSR 5: 240-307. (In Russian.)

CHEN C.L. 1973: [An Illustrated Guide to the Fish Diseases and Causative Pathogenic Fauna and Flora in the Hubei Province.] Academia Sinica Press, Beijing, 456 pp. (In Chinese.)

CHEN C., MA C. 1998: Fauna Sinica. Myxozoa, Myxosporea. Science Press, Beijing, 993 pp. (In Chinese.)

CSABA G., KOVÁCS-GAYER É., BÉKÉSI L., BUCSEK M., SZAKOLCZAI J., MOLNÁR K. 1984: Studies into the possible protozoan aetiology of swimbladder inflammation in carp fry. J. Fish Dis. 7: 39-56.

DONEC Z.S., SHULMAN S.S. 1984: Parasitic protozoa. In: O.N. Bauer (Ed.) Key to the Parasites of Freshwater Fish of the USSR. Vol. 1. Nauka, Leningrad, 426 pp. (In Russian.)

DYKOVÁ I., LOM J. 1988: Review of pathogenic myxosporeans in intensive culture of carp (Cyprinus carpio) in Europe. Folia Parasitol. 36: 289-307.

KISZELY G., BARKA T. 1958: Gyakorlati Mikrotechnika és Histokémia. Publ. House Kossuth, Budapest, 342 pp.

KOVÁCS-GAYER É., MOLNÁR K. 1983: Studies on the biology and pathology of the common carp parasite Myxobolus basilamellaris Lom et Molnár, 1983 (Myxozoa: Myxosporea). Acta Vet. Hung. 31: 91-102.

LANDSBERG J.H., LOM J. 1991: Taxonomy of the genera of the Myxobolus/Myxosoma group (Myxobolidae: Myxosporea), current listing of species and revision of synonyms. Syst. Parasitol. 18: 165-186.

LIYANAGE S.Y., YOKOYAMA H., MATOYAMA H., HOSOYA H., WAKABAYASHI H. 1998: Experimentally induced haemorrhagic thelohanellosis of carp caused by Thelohanellus hovorkai (Myxosporea: Myxozoa). Fish Pathol. 33: 489-494.
LOM J., ARTHUR J.R. 1989: A guideline for the preparation of species descriptions in Myxosporea. J. Fish Dis. 12: 151-156.

LOM J., MOLNÁR K. 1983: Myxobolus basilamellaris sp. $\mathrm{n}$. (Myxozoa, Myxosporea) parasite of the gills of common carp (Cyprinus carpio L.). Folia Parasitol. 30: 1-3.

MOLNÁR K. 1979: Gill sphaerosporosis in the common carp and grasscarp. Acta Vet. Hung. 27: 99-133.

MOLNÁR K. 1980: Renal sphaerosporosis in the common carp Cyprinus carpio L. J. Fish Dis. 3: 11-19.

MOLNÁR K. 1982: Biology and histopathology of Thelohanellus nikolskii Achmerov, 1955 (Myxosporea, Myxozoa), a protozoan parasite of the common carp (Cyprinus carpio). Z. Parasitenkd. 68: 269-277.

MOLNÁR K. 2000: Myxobolus intrachondrealis sp. $\mathrm{n}$. (Myxosporea: Myxobolidae), a parasite of the gill cartilage of the common carp, Cyprinus carpio. Folia Parasitol. 47: 167-171.

MOLNÁR K. 2002: Differences between the European carp (Cyprinus carpio carpio) and the coloured carp (Cyprinus carpio haematopterus) in susceptibility to Thelohanellus nikolskii (Myxosporea) infection. Acta Vet. Hung. 50: 5157.

MOLNÁR K., KOVÁCS-GAYER É. 1982: The occurrence of two Far-East origin Thelohanellus (Myxosporidia) species in common carp populations of the Hungarian pond farms. Parasitol. Hung. 14: 51-55.

MOLNÁR K., KOVÁCS-GAYER É. 1985: The pathogenicity and development within the fish host of Myxobolus cyprini Doflein, 1898. Parasitology 90: 549-555.

MOLNÁR K., FISCHER-SCHERL T., BASKA F., HOFFMANN R. 1989: Hoferellosis in goldfish Carassius auratus and gibel carp Carassius auratus gibelio. Dis. Aquat. Org. 7: 89-95. 
PAN J.H., ZHANG J.Y., LI Z.C. 1990: Fish Parasitology. Science Press, Beijing, 443 pp. (In Chinese.)

PÉNZES B., TÖLG I. 1986: Az aranyhal és a koi. Mezőgazd. Kiadó, Budapest, 211 pp.

SHARPLES A.D., EVANS C.W. 1996: Pathology of fin erosion in goldfish (Carassius auratus). Dis. Aquat. Org. 24: 81-91.

SZÉKELY C., MOLNÁR K. 1996-1997: Preliminary survey of the parasite fauna of some important fish species in the Upper Reservoir of the Kis-Balaton system. Parasitol. Hung. 29-30: 45-54.

YOKOYAMA H., OGAWA K., WAKABAYASHI H. 1993: Involvement of Branchiura sowerbyi (Oligochaeta:
Annelida) in the transmission of Hoferellus carassii (Myxosporea: Myxozoa), the causative agent of kidney enlargement disease (KED) of goldfish Carassius auratus. Fish Pathol. 28: 135-139.

YOKOYAMA H., OGAWA K., WAKABAYASHI H. 1995: Myxobolus cultus n. sp. (Myxosporea: Myxobolidae) in the goldfish Carassius auratus transformed from the actinosporean stage in the oligochaete Branchiura sowerbyi. J. Parasitol. 81: 446-451.

ZARDOYA R., DOADRIO I. 1999: Molecular evidence on the evolutionary and biogeographical patterns of European cyprinids. J. Mol. Evol. 9: 227-237. 